\title{
Managing Evidence-Based Research Processes with Systematic Review and Bibliometric Analysis Methods in Covid-19 Pandemic
}

\section{Covid-19 Pandemisinde Sistematik İnceleme ve Bibliyometrik Analiz Yöntemleri ile Kanıta Dayalı Araştırma Süreçlerini Yönetme}

(i) Kübra ZAYIM GEDIK¹, id Özlem YALÇINKAYA, id Bahattin YALÇINKAYA²

${ }^{1}$ Bezmialem Vakıf University Vocational School of Health Services, Medical Documentation and Secretarial Program/Library and

Documentation Directorate, İstanbul, Turkey

${ }^{2}$ Marmara University Faculty of Arts and Sciences, Information and Records Management, Istanbul, Turkey

\begin{abstract}
Objective: This article aims to analyze different approaches to a literature review. The publications in the pandemic period were examined by bibliometric analysis method within the framework of systematic review and determined criteria.
\end{abstract}

Methods: Between 01.01.2020 and 07.06.2020, research on pandemics in WOS and Scopus platforms has been examined with a comprehensive literature study. The first aim of the study is to reveal the quality of the literature research. Another goal is to analyze the results with certain criteria. The bibliometric analysis method was used to analyze the results of the research.

Results: With the determined research strategy, the publications belonging to the pandemic period were analyzed comparatively with charts and tables in WOS and Scopus platforms such as country, type of publication, institution, subject area, author, the most cited publication, and the most published journals.

Conclusion: Within the framework of bibliometric analysis, it is one of the top contributors in the process with the highest number of publications in the US pandemic process. Although there is no direct relationship between the intensity of spreading of the pandemic and the publications produced, these two processes have proceeded almost parallel to each other. It has been determined that

\section{ÖZ}

Amaç: $\mathrm{Bu}$ makale bir literatür taramasına farklı yaklaşımları analiz etmeyi amaçlamıştır. Pandemi döneminde üretilen yayınlar, sistematik inceleme ve belirlenen kriterler çerçevesinde bibliyometrik analiz yöntemi ile incelenmiştir.

Yöntemler: 01.01.2020-07.06.2020 tarihleri arasında WOS ve Scopus platformlarında pandemiyle ilgili yapılan araştırmalar, kapsamlı bir literatür çalışmasıyla incelenmiştir. Çalışmanın ilk hedefi literatür araştırmasının kalitesini ortaya koymaktır. Diğer hedefi ise ortaya çıkan sonuçları belirli kriterlerle analiz edebilmektir. Araştırma sonuçlarının analiz edilmesinde bibliyometrik analiz yöntemi kullanılmıştır.

Bulgular: Belirlenen araştırma stratejisiyle birlikte, pandemi dönemine ait yayınlar, WOS ve Scopus platformlarında ülke, yayın türü, kurum, konu alanı, yazar, en çok atıf alan yayın ve en çok yayın yapılan süreli yayınlar gibi kriterler seçilerek karşılaştırmalı olarak, grafik ve tablolarla analiz edilmiştir.

Sonuç: Bibliyometrik analiz çerçevesinde ABD pandemi sürecinde en fazla yayın sayısıyla sürece en çok katkı sağlayan devletlerin başında gelmektedir. Pandeminin yayılma yoğunluğu ile üretilen yayınlar arasında doğrudan bir iliş̧ki olmamasına rağmen, bu iki süreç neredeyse birbirine paralel şekilde ilerlemiştir. En çok
Address for Correspondence: Kübra ZAYIM GEDiK, Bezmialem Vakıf University Vocational School of Health Services, Medical Documentation and Secretarial Program/Library and Documentation Directorate, istanbul, Turkey E-mail: kzayim@bezmialem.edu.tr ORCID ID: orcid.org/0000-0001-7945-3480

Cite this article as: Zayim Gedik K, Yalçınkaya Ö, Yalçınkaya B. Managing Evidence-Based Research Processes with Systematic Review and Bibliometric Analysis Methods in Covid-19 Pandemic. Bezmialem Science 2020;8(4):418-427.

${ }^{\circledR}$ Copyright 2020 by the Bezmiâlem Vakıf University

Bezmiâlem Science published by Galenos Publishing House.
Received: 09.06.2020

Accepted: 29.06 .2020 
the most broadcasting institutions are universities in the USA. In this process, it was seen that most of the articles were published in order to ensure the rapid dissemination of scientific information. In the fight against epidemic, it has been observed that quite a lot of publications have been produced in the field of medicine on both platforms.

Keywords: Systematic review, meta-analysis, bibliometry, research design, COVID-19, pandemic yayın üreten kurumlar yine ABD'deki üniversiteler olduğu tespit edilmiştir. Bu süreçte bilimsel bilginin hızlı bir şekilde yayılmasını sağlamak amacıyla en çok makale türünde yayın üretildiği görülmüştür. Salgınla mücadelede iki platformda da tıp alanında oldukça fazla yayın üretildiği görülmüştür.

Anahtar Sözcükler: Sistematik inceleme, meta-analiz, bibliyometri, araştırma tasarımı, COVID-19, pandemi

\section{Introduction}

Research methods in medicine and health sciences are updated and developed with the developments in this field. With the Covid-19 pandemic, researchers have aimed to produce research with high evidence level in order to develop a rapid diagnosistreatment method in a short time. Online literature search tools cover most disciplines and make millions of scientific data searchable in seconds. For this reason, the researches should be subject to a careful literature review and repetition should be avoided in search results. In this process, methods such as systematic review, meta-analysis and bibliometric analysis are considered as important methods for evidence synthesis. Scopus and Web of Science (WOS) are two important research platforms that index the best journals in all disciplines. Within the scope of the study, scientific research belonging to the Covid-19 pandemic period was evaluated according to various criteria using bibliometric analysis method on these two platforms. Systematic review methods in evidence-based research processes were also indirectly addressed in the study. In addition, the subject of evidence-based research was included in this study for the information about databases used in systematic review and meta-analysis processes and the content in the method.

The increasing volume of scientific research makes it increasingly difficult for practitioners and researchers to follow past and current findings in a particular discipline. The field of medicine and health sciences is developing very rapidly in terms of research volume compared to other disciplines. The use of different techniques and methods in medicine and health sciences and the development of medical applications with the changing technology have also been reflected in the medical literature. For this reason, it is known that researchers and practitioners in the field of medicine and health sciences tend to increase the level of evidence in their research with the most up-to-date publications in order to manage research processes. In the process of the Covid-19 pandemic, when the research outputs made in 2020 from the date accepted as the beginning of the pandemic until today are examined, it has been revealed that the cited sources are quite old publications. This situation reveals how important it is to examine all relevant scientific outcomes in affecting the level of evidence within the scope of the research subject. For this reason, researchers and practitioners should know and use research tools with high publication level in their discipline, and increase the level of evidence studies with various research methods.

\section{Evidence-based Research}

Evidence-based research has been adopted as an approach for professionals and / or other decision-makers in a particular field, in which evidence showing which method to be used in which application is identified and information about how scientifically strong these users are is given.

In the field of medicine and health, it is very important that the information is up-to-date, correct, reliable, accessible and based on evidence. Factors such as the increase in the amount and speed of all kinds of information produced, the safe access to information sources, easy use and continuous updating of the sources, the emergence of new types of studies for research, the development of new databases by examining and evaluating the evidence values of the researches, and the concepts of cost, quality and efficiency gaining importance day by day especially in medical and health sciences have made the approach of evidencebased research necessary and important.

The practices and approaches that emerge with evidence-based research affect the field of medicine and health most, as well as all disciplines. Among the different user groups in the field of health, the group that needs the most up-to-date and urgent information is the academicians in the field of medicine. In parallel with this, various user studies on the need for evidencebased information and information seeking behavior of user groups working in medicine and health sciences have emerged intensively.

Evidence-based research has required the information to be supported by a systematic approach with qualified and up-todate research in order to make the right decisions. Among the most important elements of using the best evidence to guide the practice of any professional, there is development of questions using research-based evidence, the level and types of evidence to be used, and evaluation of the effectiveness after the task or effort is completed (1). Evidence-based knowledge is one of the most important and sought information types by academics and practitioners in the medical field.

Today, the number of scientific studies in the field of medicine and health sciences is increasing rapidly. Often different results are obtained in studies conducted on a particular subject, independently from each other. In order to interpret this mass of knowledge and use it in new research, comprehensive and reliable further studies are needed. With the applications of evidence- 
based medicine (EBM), new sources that provide analysis of researches on a specific subject have come to the fore (2).

Although all sources that provide evidence information presents evidence, the levels of evidence vary (3).

Evidence-based research methods are grouped differently in different sources. It is most commonly studied at the following four basic levels. In our study, the first two analysis methods within the second of these levels are mentioned.

\section{Original studies}

2. Resources that synthesize original studies

\section{Resources summarizing original studies}

4. Systems that provide access to original studies, their synthesis and contents (2).

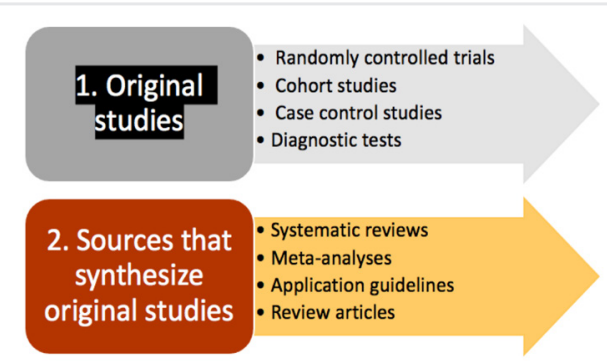

Figure 1. Classification of sources according to levels of evidence

As stated above, it is possible to examine studies classified according to evidence levels under these two headings. The first of these offers original primary sources. The important feature of original studies is that they provide evidence information. Evidence-based information is obtained directly from the field. The second is considered as sources synthesizing original studies that form the level of evidence. Secondary sources are generally considered as studies that guide the researcher with literature reviews and shed light on obtaining original results. The first two levels can also be expressed by the following evidence quality pyramid

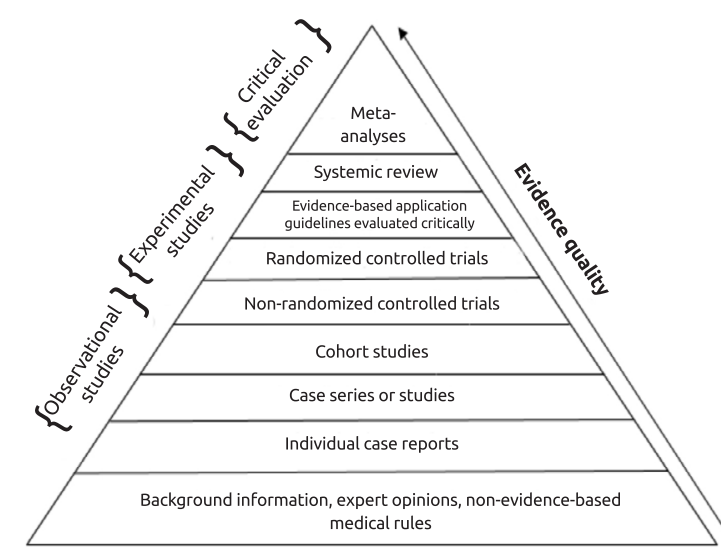

Figure 2. Evidence quality pyramid
The evidence pyramid is explained in various versions. The feature common to all of them is that it focuses on showing weak study designs (basic science and case series) at the bottom, followed by case-control and cohort studies in the middle, then followed by randomized controlled trials (RCTs), and at the top are systematic reviews and meta-analysis studies.

It is emphasized in the lowest ranking that the lower sources of evidence in the hierarchy are the least preferred in practice because it takes more expertise and time to define, evaluate and apply true and most appropriate evidence. Meta-analysis studies, on the other hand, are the highest evidence in the hierarchy, and include those with clinical, methodological or statistical reliability, in which the estimation of treatment results varies greatly depending on the analytical strategy used. There are systematic reviews at the top of the evidence pyramid. In the American Medical Association Journal Guideline, systematic reviews and meta-analysis studies provide a general framework. The guideline presented a two-step approach in which the reliability of a systematic review process was first evaluated (a comprehensive literature review, rigorous study selection process, etc.). If the systematic review is considered reliable enough, the second step is taken where we evaluate the certainty in evidence based on the GRADE approach. In other words, RCTs that are well managed at low risk of bias cannot be meta-analyzed. Therefore, the second modification of the pyramid is necessary to extract systematic reviews from the top of the pyramid and use them as a lens for other types of work to be seen (i.e. evaluated and implemented). Systematic review (the process of selecting studies) and meta-analysis (statistical aggregation that produces a single effect size) are tools for using and applying stakeholder evidence (4).

It is known by everybody that systematic review and metaanalysis are the most used methods especially in scientific studies in the field of health and are important in academic studies. When using systematic review and meta-analysis methods, many scientific sources are needed and care is taken to make these sources especially evidential sources. Like other producers of systematic reviews, it requires authors to provide a repeatable and detailed plan for evaluation of evidence and literature review (5).

\section{Systematic Review}

In parallel with the rapid increase of knowledge in medicine and health, the sources of information in which medical information is published vary. One of the most important aspects that increase the quality of the research is that the relevant literature in the field of research has been thoroughly scanned. Today, with the large number of research outputs in many research platforms and databases, it has become very difficult for researchers to search and identify suitable outputs. Systematic review is the evolution of the literature review, including planning, execution, analysis, synthesis and reporting processes (6). Systematic reviews are secondary sources that collect, analyze and synthesize the findings of many primary sources that report the research process and findings. These reviews are the most important sources of EBM practices as the sources that provide the highest level of evidence 
among the sources providing evidence-based information. These evidence-based sources addressing a specific health problem are prepared by applying scientific methods in collecting all relevant primary research sources, evaluating these sources with a critical approach and synthesizing their findings (7).

In the planning process, which is the first stage of systematic review, the research subject must be defined. In this process, the researcher must be a knowledge master on systematic review. This stage also includes critical thinking. For planning, which is the first stage of the systematic review, there are two methods used as PICOC (Population-Intervention-Comparison-OutcomeContext) and CIMO (Context-Intervention-MechanismOutcome) (6).

The second stage of systematic review is the execution stage consisting of research, selection and evaluation. In a systematic review, the first purpose of the search phase is to identify all or as much of the relevant resources as possible (8). For this reason, a research platform should be chosen that will best cover the research subject. Research tools are important in terms of the subject area, the type of resource it contains, the year range of research outputs, and the inclusion of all research from around the world and a not making geographical separation. The sources resulting from the research are selected and the process of evaluating the quality of evidence within the scope of the research subject is completed at this stage.

The third stage of systematic review is analysis and synthesis. In the following sections of the study, the processes of transforming the data obtained through systematic analysis into meaningful findings with bibliometric analysis and meta-analysis will be covered in detail.

The last stage of the systematic review is the reporting stage. At this stage, it is aimed to transform the information and findings obtained through systematic review into outputs. During the reporting phase, models such as the PRISMA model can be used technically.

\section{Evidence-based Research Databases Including Systemic Review and Meta-analysis}

Databases and Search Systems: Pubmed (MEDLINE), Embase, Cochrane Library, CINAHL, Web of Science, APA PsycInfo, Global Health, Scopus, DynaMed, EbscoHost, ERIC, Google Akademik, LILACS, Nursing Reference Center, ProQuest, PsycINFO, ScienceDirect, Scopus, SportDiscus, TRID, OVID, Roadrunner Search.

Clinical Trials: ClinicalTrials.gov, European Clinical Trials Register, International Standard Randomized Clinical Trial Number (ISRCTN) Register, World Health Organization (WHO) International Clinical Trial Registry Platform.

Gray literature: ProQuest Dissertations \& Theses.

\section{Bibliometric Analysis}

The main goal of scientific research is to reach significant results from the research outputs achieved on the study subject together with the systematic review. In this process, meta-analysis and bibliometric analysis methods are the most important stages of the research in reaching meaningful results. Bibliometry has been used extensively in evaluating scientific outcomes by analyzing the structure of disciplines and their development. With the bibliometric analysis method, various findings regarding scientific communication are obtained by analyzing certain features of documents or publications in bibliometric research (9). Bibliometric methods are a useful aid in literature reviews even before reading, by guiding the researcher to the most effective studies and mapping the research area without subjective bias (10). Bibliometric analysis is complementary in addition to systematic review and meta-analysis methods which are used as traditional methods in evidence-based research processes and complement each other.

There are varieties of bibliometry that analyze publication metrics, journal metrics, citation metrics, network metrics, research impact metrics, and research impact enhancement processes. There are different content evaluation methods for the mentioned metrics. In publication metrics, information such as publication year, institution, publication name, subject area, author, funding institution and type of publication can be reached and analyzed. In this study, researches on Covid-19 were analyzed with the data obtained from WOS and Scopus platforms with the bibliometric analysis method. Journal metrics are analyzed using Journal Impact Factor (JIF) and Scimago Journal and Country Ranking (SJR) platforms in analysis processes. In bibliometric analysis processes, data obtained from databases and various platforms can also be analyzed using various software tools such as Gephi, Sci2, CitNetExplore, VosViewver and ID3 Algorithm (6).

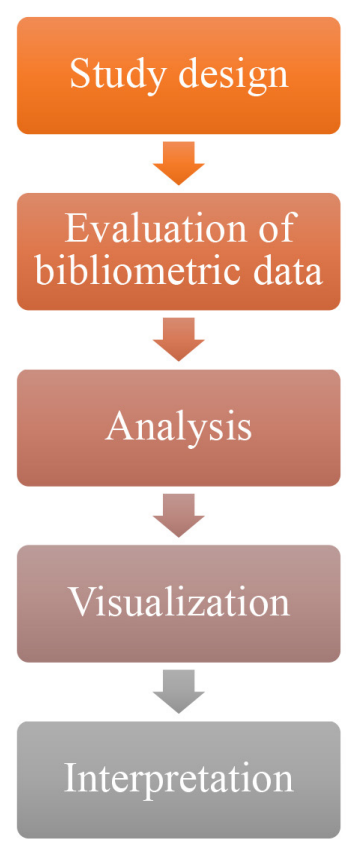

Figure 3. Workflow for science mapping with bibliometric methods (10). 
All stages of bibliometric analysis are carried out with systematic review. It includes the processes of having systematic review skills, determining the research subject and determining the research method during the research design phase. This stage is common with the first stage of systematic review. It is the stage of scanning the research subject with various criteria by deciding on the database during the compilation of bibliometric data and obtaining the data. The data obtained are stored in a meaningful integrity with various computer programs and defined with various tools during the analysis phase. In the visualization phase, the data obtained are visualized through softwares such as VosViewver. In the last stage, the findings are defined and interpreted with the researcher's expertise in that field and evidence synthesis.

\section{Method}

This study aims to support research with high level of evidence by using systematic review and bibliometric analysis methods in the field of medicine and health sciences during the Covid-19 pandemic. The study also developed a Covid-19 search strategy enabling research within data sources and databases used in systematic review and meta-analysis processes in line with certain criteria. In addition, the subject of evidence-based research was included for the information about databases used in systematic review and meta-analysis processes and the content in the method.

In this study, the researches on the Covid-19 pandemic on the Web of Science (WOS) and Scopus platforms between January 1, 2020 and June 7, 2020 were examined with a comprehensive literature review.

The first goal of the study is to reveal the quality of the literature research. The other goal is to analyze the results with certain criteria. The bibliometric analysis method was used to analyze the research results. At the beginning of the research, two different research strategies were determined for the scanning to be done in WOS and Scopus. First, keywords were determined in order to examine the Covid-19 research outputs in detail. The keywords were chosen commonly for the two platforms. Scanning has been carried out on both platforms with the specified search words. Afterwards, the research conducted on WOS and Scopus platforms were analyzed in terms of the country, type of publication, institution, subject area and the number of citations received by the most publishing author. While analyzing the data, SPSS 22 software and Excel program for table views were used.

\section{Scopus Search Strategy}

"Wuhan coronavirus" OR "Wuhan seafood market pneumonia virus" OR "COVID19*” OR "COVID-19*” OR "COVID-2019*" OR "coronavirus disease 2019" OR "SARSCoV-2" OR sars2 OR "2019-nCoV” OR "2019 novel coronavirus" OR "severe acute respiratory syndrome coronavirus 2" OR "2019 novel coronavirus infection" OR "coronavirus disease 2019" OR "coronavirus disease-19" OR "novel coronavirus" OR coronavirus OR "SARS-CoV-2019" OR "SARSCoV-19” AND ( LIMIT-TO ( PUBYEAR, 2020 ).

\section{Web of Science-Core Collection Search Strategy}

("Wuhan coronavirus" OR "Wuhan seafood market pneumonia virus" OR "COVID19*” OR "COVID-19*” OR "COVID-2019*” OR "coronavirus disease 2019” OR "SARSCoV-2" OR SARS2 OR "2019-nCoV” OR "2019 novel coronavirus" OR "severe acute respiratory syndrome coronavirus 2" OR "2019 novel coronavirus infection" OR "coronavirus disease 2019" OR "coronavirus disease-19" OR "novel coronavirus" OR coronavirus OR "SARS-CoV-2019" OR "SARSCoV-19")

Refined by: PUBLICATION YEARS: ( 2020 )

\section{Results and Discussion}

Covid-19 originated in Wuhan, China and spread to European countries and later to America. With the spread of the epidemic to different continents, the World Health Organization (WHO) declared the disease Covid-19, caused by the new corona virus, as a pandemic. It is understood from the statistics that there has been a rapid increase in the number of publications made on this issue in a very short time.

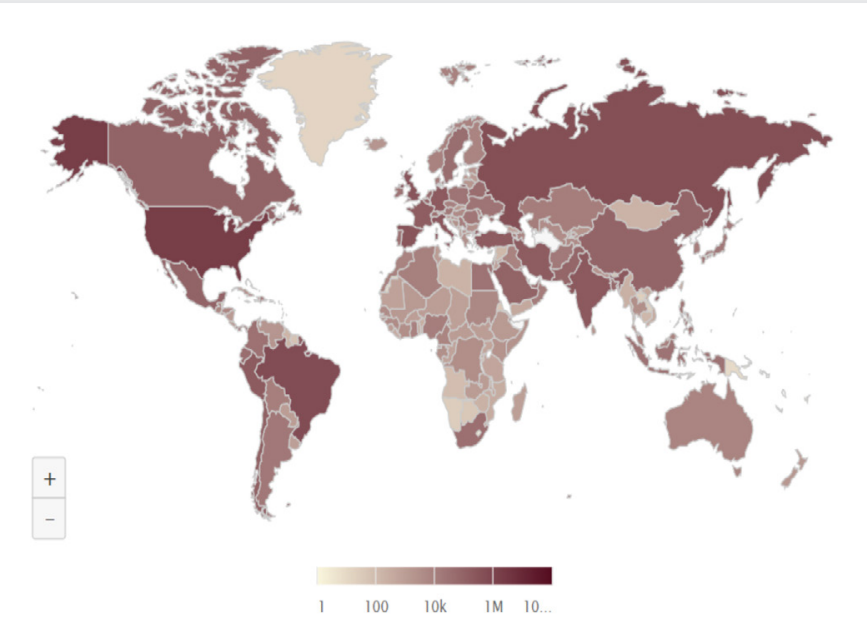

Figure 4. General situation of the Covid -19 outbreak in the world (02.06.2020)

Source: https://www.worldometers.info/coronavirus/worldwidegraphs/\#countries-deaths

Along with the research strategy determined in the research method, the publications produced in the Covid-19 period were selected considering criteria including country, publication type, institution, subject area, author, the most cited publication and the most published periodicals on WOS and Scopus platforms and analyzed comparatively with graphs and tables.

There is quite a difference between the numbers of results of searches in both platforms performed using the keywords created among the Pubmed $\mathrm{MesH}$ terms. It was concluded that during the Covid-19 pandemic period, 18942 publications were carried out in Scopus and 7689 in WOS. The reason for this can be attributed to the different publication selection criteria of both platforms. The most cited publication on the WOS platform in the time interval of research was published in the Lancet journal 
with 1217 citations. The most cited publication on the Scopus platform was again from Lancet with 2094 citations.

The criteria specified within the scope of the study have been analyzed with the tables below.

Table 1. The number of publications carried out in some countries according to Scopus

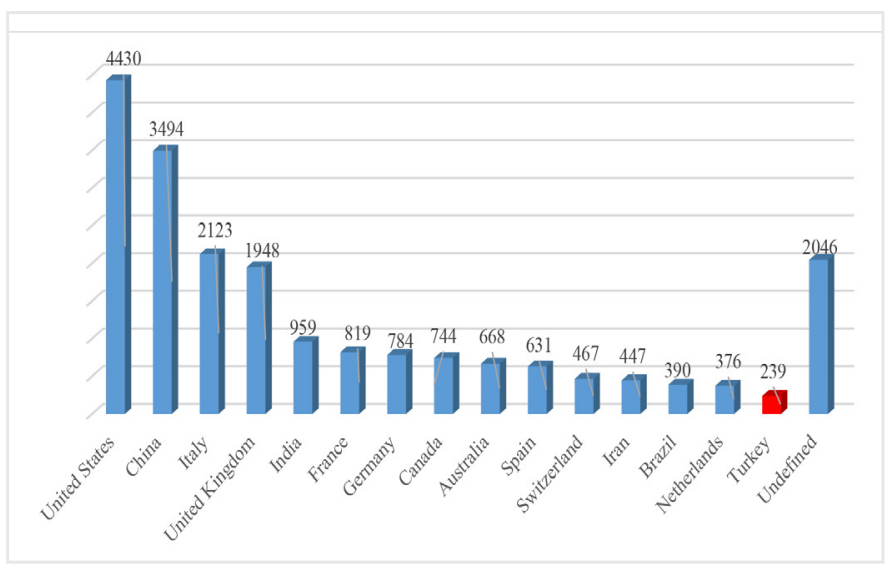

According to the analyses made in the Scopus database, the USA has the highest number of publications among the first fifteen countries. 4430 publications $(23.3 \%)$ were performed in the USA. This was followed by China with 3294 (17.3\%), Italy with $2123(11.2 \%)$ and the United Kingdom with 1948 (10.2\%) publications. Although there is no direct relationship between the spread density of the pandemic and the publications performed, we can say that these two tables are almost coordinated with each other. An important detail here is the publications with no country specified. 2046 publications (10.8\%) seen in the table as undefined are in a very important position. Turkey has contributed this scientific process with 239 publications (1.2\%).

Table 2. The number of publications carried out in some countries according to WOS

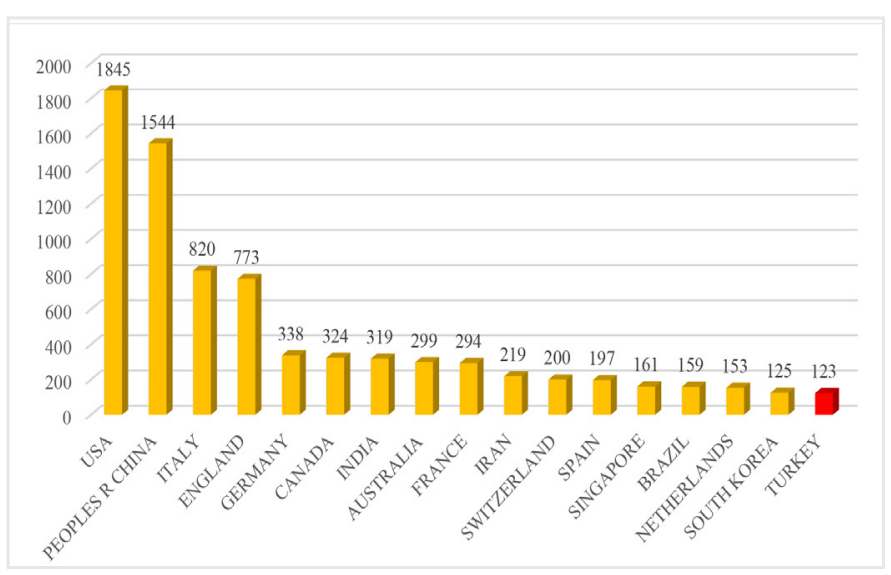

According to the analyses made in the WOS database, the USA ranked first in terms of the number of publications, just like the Scopus database. The USA performed 1845 publications
$(23.99 \%)$ in this period. It was followed by China with 1554 (20.08\%), Italy with $820(10.66 \%)$, and England with 773 (10.05\%) publications. The similarities with the Scopus database draw attention in the ranking of publication production. Turkey has contributed with 123 articles (1.6\%) to this process.

Table 3. Types of publications conducted according to Scopus

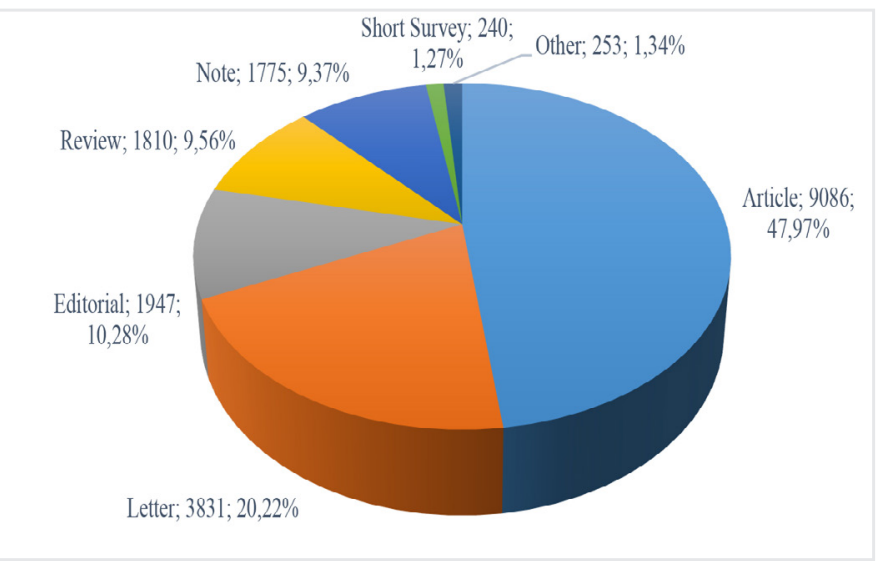

Almost half of the publications performed consist of articles in the Scopus database. This rate is $47.97 \%$. The articles are followed by letters with $20.22 \%$ and editorial reviews with $10.28 \%$.

Table 4. Types of publications conducted according to WOS

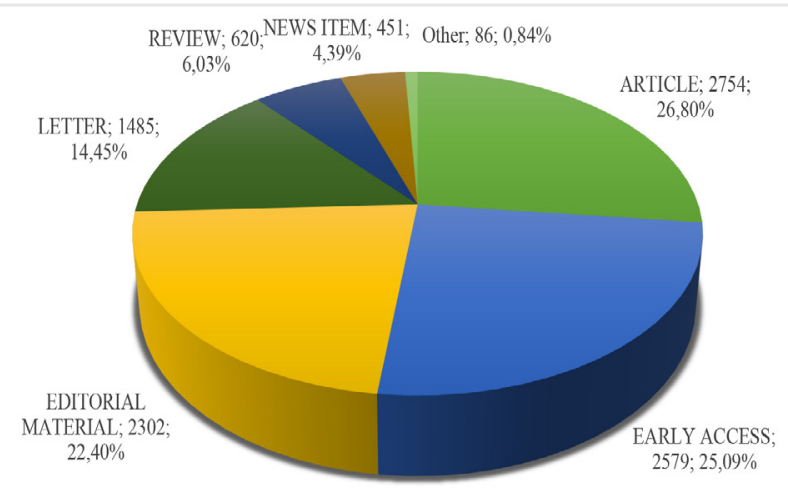

The numbers in the WOS database are identical to the numbers in the Scopus database. $51.89 \%$ of the publications between January 1, 2020 and June 7, 2020 were performed as articles. Moreover, almost half of these articles were opened to early view before their publication date. It should be evaluated as a very important datum in terms of showing the speed of scientific developments on this subject. Other publications produced in WOS are editorial reviews with $22.4 \%$ and letters with $14.45 \%$. It is seen that the rates of articles are the highest as research outputs on both platforms. 
Table 5. Subject distributions of publications in Scopus

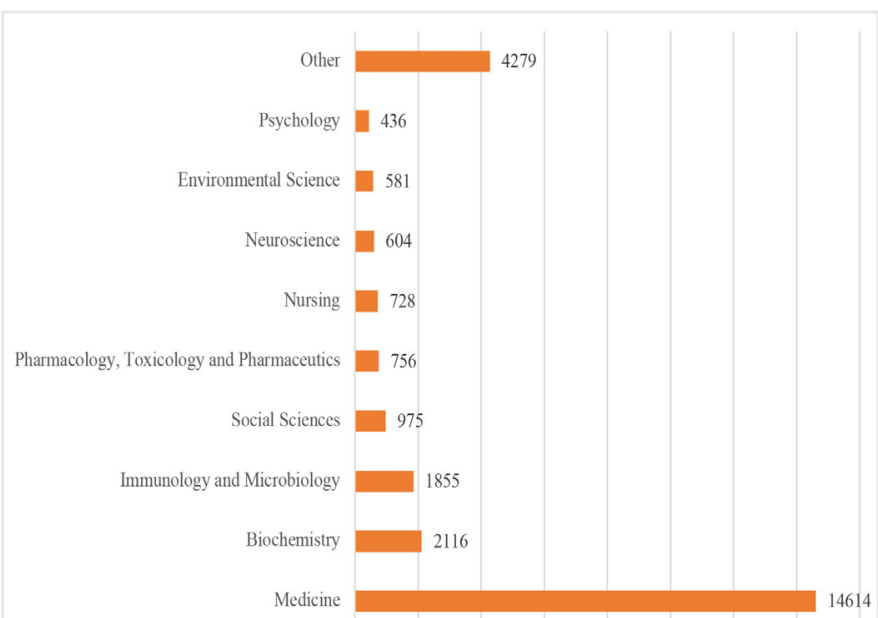

When the data in the Scopus database were analyzed, it was seen that 14614 of the publications were performed in the field of medicine. Medicine is followed by biochemistry with 2116, immunology and microbiology with 1855 publications. What is interesting in this table is that social sciences were in the fourth place according to Scopus data. In fact, when evaluating the data, $77.15 \%$ of the total publications were in the field of medicine, while $5.1 \%$ were in the field of social sciences. From this point of view, it can be evaluated that the consequences of the pandemic affecting the whole world have an important place in terms of social sciences. One of the supporting figures in the table is that $436(2.3 \%)$ publications have been performed in the field of psychology. It is estimated that the pandemic will decrease its impact and the number and rate of studies to be carried out in this field will increase in the following years.

Table 6. Subject distributions of publications in WOS

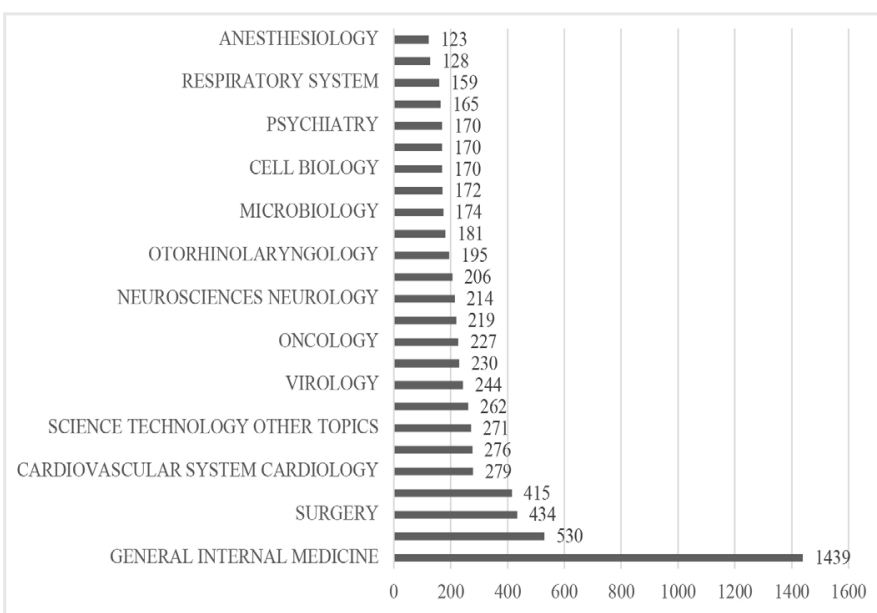

The WOS platform reveals specifically the medical sciences with a more detailed analysis. Of the publications, $18.71 \%$ are in the field of general medicine, $6.83 \%$ are in the context of public health, 5.6\% are in the field of surgery. When the data in the WOS database were examined, it can be witnessed that medical sciences are seeking solutions for the pandemic with great effort.
Methods in the field of diagnosis-treatment and medicine have played an important role in combating the disease. It has been observed that quite a lot of publications have been performed in the field of medicine on both platforms in the fight against the epidemic.

Table 7. Number of Publications Produced by the Top Publishing Institutions in Scopus

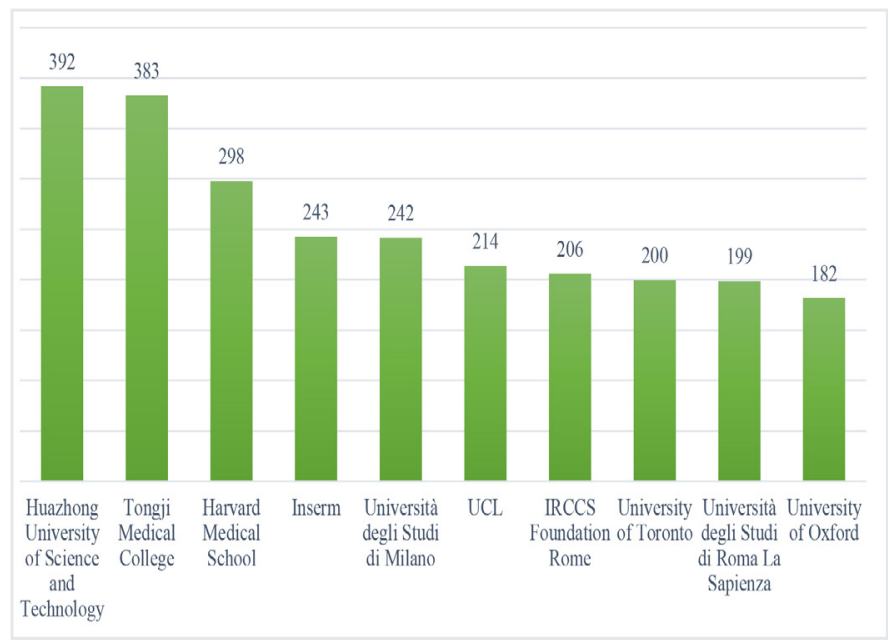

In the Scopus platform, the institutions producing the highest number of publications in the Covid-19 pandemic and their contribution percentages are as follows; Huazhong University of Science and Technology 392 (2.06\%), Tongji Medical College 383 (2.02\%), Harvard Medical School 298 (1.57\%), Inserm 243 (1.28\%), Università degli Studi di Milano 242 (1.27\%).

Table 8. Number of Publications Produced by the Top Publishing Institutions in WOS

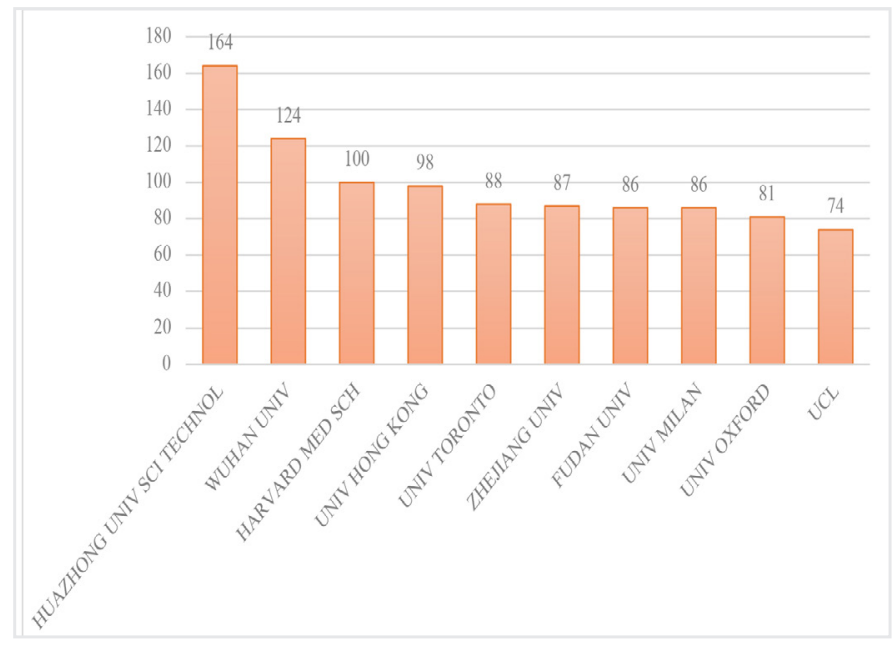

The institutions producing the highest number of publications and their contribution percentages in the Covid-19 pandemic in the WOS platform in 2020 are as follows; 3.2\% University of London, 2.3\% Harvard University, 2.2\% University Of California System, 2.17\% Huazhong University Of Science Technology and 1.6\% Wuhan University. 
Table 9. Top publishing authors according to Scopus

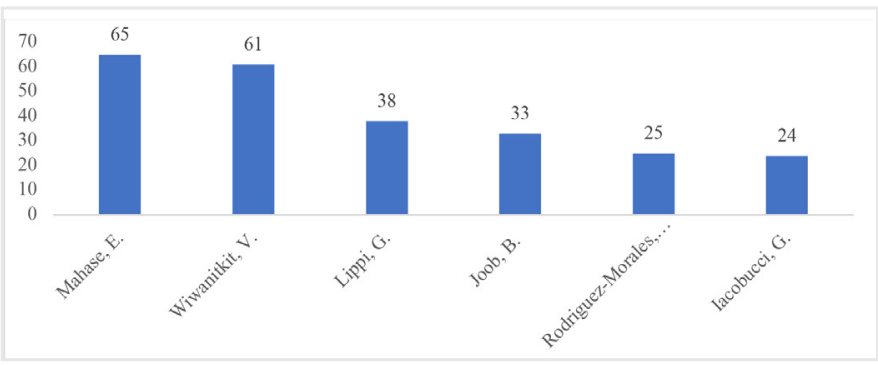

The most frequently publishing authors on the Scopus platform are listed in the table above. As it can be seen in the first row, the fact that a single author conducted 65 publications in about 180 days shows that scientists have worked hard to contribute to this period.

Table 10. Top publishing authors according to WOS

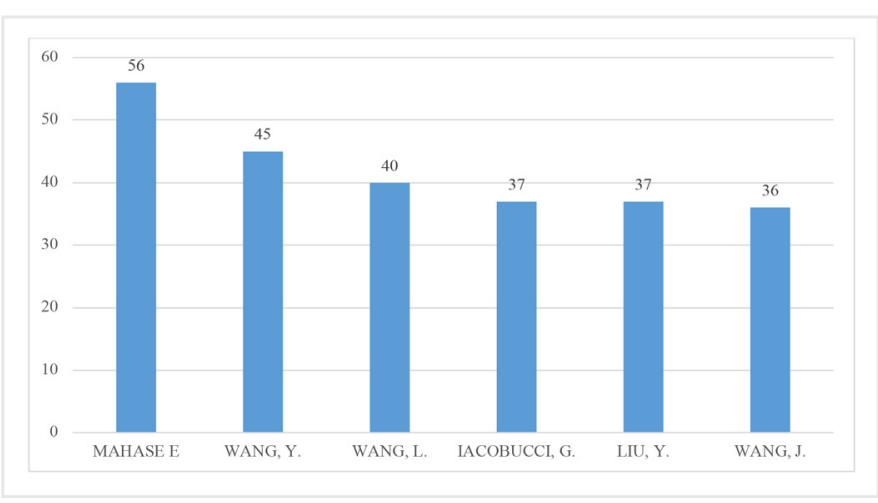

In the WOS platform, the contribution of anonymous authors appears to be 177 publications. Just like Scopus platform, Masahe, E. came first on this platform. A total of 121 publications of the author were published in the period subject to research on both platforms. It can be evaluated as a remarkable author performance in terms of making a very important contribution.

Table 11. The periodicals publishing the highest number of studies on WOS and Scopus platforms

\begin{tabular}{l|l|l|l|}
\hline WOS & $\begin{array}{l}\text { Number of } \\
\text { publications }\end{array}$ & $\begin{array}{l}\text { Source } \\
\text { Source }\end{array}$ & $\begin{array}{l}\text { Number of } \\
\text { publications }\end{array}$ \\
$\begin{array}{l}\text { BMJ British } \\
\text { Medical Journal } \\
\text { Lancet }\end{array}$ & 364 & $\begin{array}{l}\text { Research Ed } \\
\text { Journal Of } \\
\text { Medical Virology }\end{array}$ & 269 \\
\hline $\begin{array}{l}\text { Journal of } \\
\text { Medical } \\
\text { Virology }\end{array}$ & 144 & BMJ & 246 \\
\hline $\begin{array}{l}\text { Cureus } \\
\text { Nature }\end{array}$ & 96 & $\begin{array}{l}\text { Lancet } \\
\text { JAMA Journal } \\
\text { Of The American } \\
\text { Medical }\end{array}$ & 153 \\
\hline & 92 & \begin{tabular}{l} 
Association \\
\hline
\end{tabular} &
\end{tabular}

The journal publishing the highest number of studies on the WOS platform was the British Medical Journal (BMJ) with 364 publications and took place in $4.7 \%$ of the total research volume. Lancet was second with 144 publications (1.8\%), followed by Journal of Medical Virology with 137 publications (1.7\%), Cureus with $96(1.2 \%)$, and Nature with 92 publications (1.19\%). In Scopus, BMJ Clinical Research journal took the first place with 269 publications. On the Scopus platform, more publications were indexed in BMJ and Lancet journals compared to WOS.

It was seen that the most cited publications in the time interval of the research were also among the journals in Table 11. The most cited study was published in the Lancet journal with 1217 citations.

\section{Conclusion}

In the study, the importance of systematic review in research processes was emphasized and the integration of bibliometric analysis method in systematic review processes was explained. In evidence-based research processes, the selection of appropriate search systems is very important. To shorten the research period and to increase the quality of research, mastering the systematic review method provides access to the relevant literature within the scope of the research subject in a short time. With bibliometric analysis, it is possible for researchers to obtain and analyze information about the structure of their fields in various categories.

Within the scope of the study, a bibliometric definition was made in a certain time interval (from the period when the pandemic period was accepted to begin to today) in order to analyze the research outputs related to the Covid-19 pandemic. WOS and Scopus platforms were chosen as the source of systematic review. Research contributions of countries and research institutions to the pandemic were evaluated on the WOS and Scopus platforms.

The United States of America (USA) is one of the countries that contributed most to the Covid-19 pandemic process with the highest number of publications. China, the starting country of the disease, remained behind USA in research processes. Although there is no direct relationship between the spread intensity of the pandemic and the publications performed, we can say that these two processes have proceeded almost parallel to each other. It has been determined that the institutions performing the highest number of publications are also the universities in USA. In this process, it was observed that articles were conducted mostly in order to ensure the rapid transmission of scientific knowledge. It has been observed that quite a lot of publications have been performed in the field of medicine on both platforms in the fight against the epidemic. However, it was observed that publications were produced in the field of social sciences with a rate of $5.1 \%$. From this point of view, it can be evaluated that the consequences of the pandemic affecting the whole world have also an important place in terms of social sciences. The fact that a single author produced a large number of publications in about 180 days shows that scientists have worked hard to contribute to this period. In this period, it is seen that studies were published 


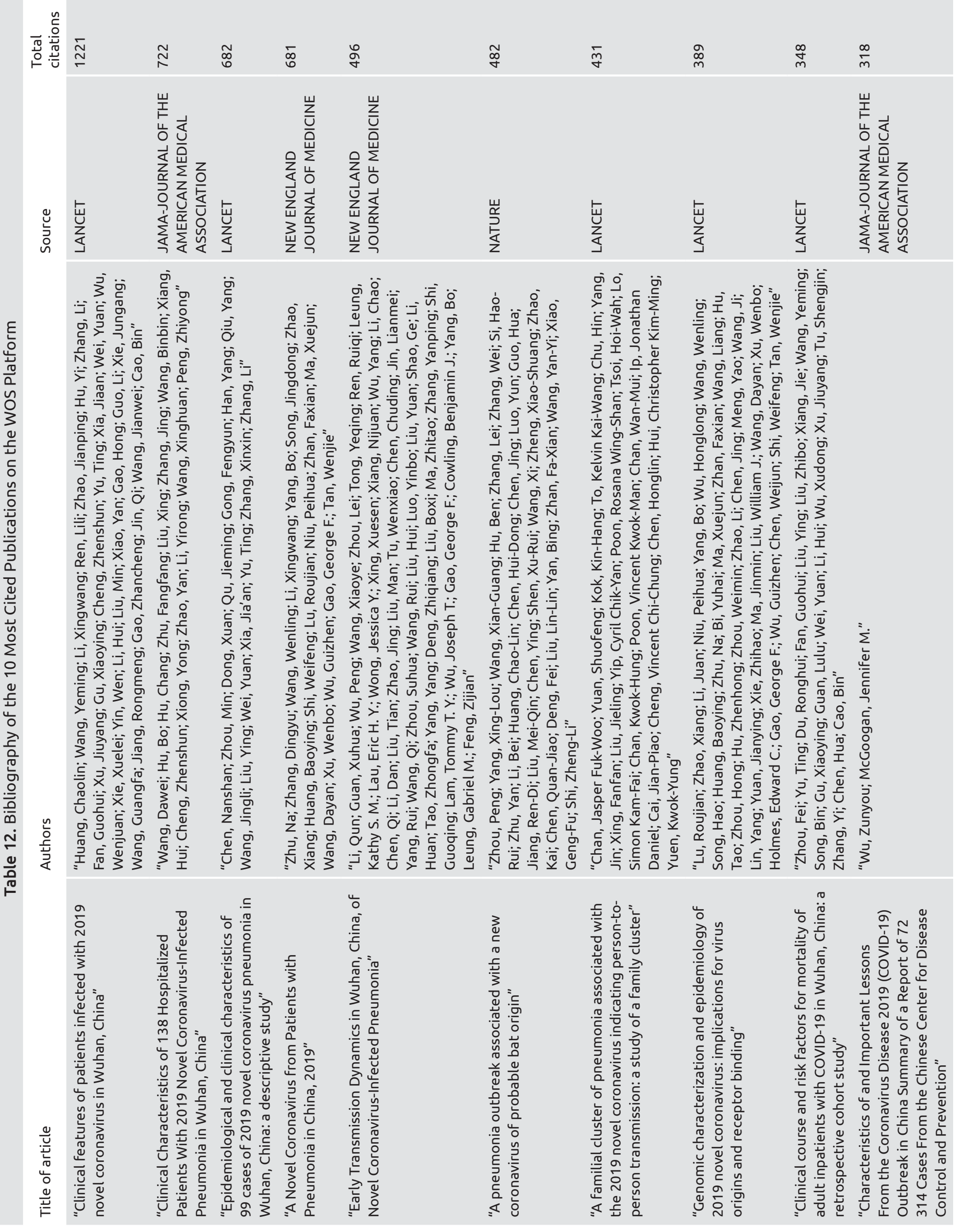


in journals with a very high impact factor in the field of health, and it was observed that the impact factor of the journals with the most cited publications during the pandemic process was quite high. The journals that contribute the most to this process and have a high number of publications have also high impact factors.

As a result, this study, which revealed studies with high evidence level by using WOS and Scopus platforms from systematic databases in the researches conducted during the Covid-19 pandemic period in the field of medicine and health sciences and by making comparative bibliometric analyses with criteria such as country, publication type, institution, subject area, author, the most cited publications and the most publishing periodicals, has also pioneered the development of the Covid-19 search strategy, which enables research within the data sources and databases used in systematic review and meta-analysis processes in line with certain criteria.

In this period, the studies in the field of medicine and health sciences to be more efficient depends on determining the evidence-based research strategy well, using the research tools in the best way and increasing the level of evidence studies with various research methods. Therefore, researchers and practitioners should tend to increase the level of evidence in their research with the most up-to-date publications primarily in order to manage research processes.

Peer-review: Internally peer reviewed.

\section{Authorship Contributions}

Concept: Ö.Y., K.Z.G., B.Y., Design: K.Z.G., B.Y., Ö.Y., Data Collection or Processing: K.Z.G., B.Y., Ö.Y., Analysis or Interpretation: K.Z.G., B.Y., Ö.Y., Literature Search: K.Z.G., B.Y., Ö.Y., Writing: K.Z.G., B.Y., Ö.Y.

Conflict of Interest: No conflict of interest was declared by the authors.
Financial Disclosure: The authors declared that this study received no financial support.

\section{References}

1. Yalçınkaya Ö. Electronic resource use in evidence-based medical librarianship. Master Thesis. Marmara University, İstanbul, 2019.

2. Uysal EK, Uçak NÖ. The evidence based information needs and information seeking behaviours of medical faculty. Bilgi Dünyası 2013;14:37-61.

3. Açıkel C. Meta-analysis and its place in evidence-based medicine. Klinik Psikofarmakoloji Bulteni 2009;19:164-172.

4. Murad MH, Asi N, Alsawas M, Alahdab F. New evidence pyramid. Evid Based Med 2016;21:125-7.

5. Tanjong-Ghogomu E, Tugwell P, Welch V. Evidence-based medicine and the Cochrane Collaboration. Bull NYU Hosp Jt Dis 2009;67:198-205.

6. Pulsiri N, Vatananan-Thesenvitz R. Improving systematic literature review with automation and bibliometrics. 2018 Portland International Conference on Management of Engineering and Technology (PICMET), Honolulu:IEEE;1-8.

7. Cook DJ, Mulrow CD, Haynes RB. Systematic reviews: synthesis of best evidence for clinical decisions. Ann Intern Med 1997;126:37680.

8. Gusenbauer M, Haddaway NR. Which academic search systems are suitable for systematic reviews or meta-analyses? Evaluating retrieval qualities of Google Scholar, PubMed, and 26 other resources. Res Synth Methods 2020;11:181-217.

9. Al U, Coştur R. Bibliometric profile of turkish journal of psychology. Türk Kütüphaneciliği 2007;21:142-63.

10. Zupic I, Čater T. Bibliometric methods in management and organization. Organ Res Methods 2015;18:429-72. 